\title{
The compliance of the Romanian listed companies with the principles and provisions of the Corporate Governance Code
}

\author{
Oana Bogdana* and Alin Dumitrescu
}

West University of Timişoara, Faculty of Economics and Business Administration, Timișoara, Romania

A B S T R A C T
Starting from the research assumption that the Corporate Governance
Code issued by Bucharest Stock Exchange (BSE) aims at building an
internationally attractive capital market in Romania, based on best
practices, transparency and trust that encourages companies to build a
strong relationship with their shareholders and other stakeholders,
communicate effectively and transparently and show openness towards all
potential investors, in this paper we would like to present the degree of
compliance of the companies listed on the Bucharest Stock Exchange with
the principles and provisions of the Corporate Governance Code. The aim
of this paper is achieved by presenting and commenting on the principles
issued by the BSE regarding the corporate governance and by analysing
the Corporate Governance Reports of the companies, presenting at the
same time the compliance of the listed companies with these principles
and provisions, by using the data issued in 2018 by the entities included in
our study, namely the listed companies on the main market of the
Bucharest Stock Exchange. Our analysis reflects that, although the
provisions and principles of the Corporate Governance Code are not
mandatory for the listed companies, they are largely implemented in the
activity of companies because an efficient corporate governance system
can represent a competitive advantage for any economic entity in the
context of globalisation.

\author{
A R T I C L E I N F O \\ Keywords: \\ comply, corporate, \\ disclosure, explain, \\ governance \\ *Corresponding author: \\ oana.bogdan@e-uvt.ro
}

Article history:

Received 15012020

Revised 25022020

Accepted 25032020

\author{
This article was presented at \\ the 8th International OFEL \\ Conference on Governance, \\ Management and \\ Entrepreneurship. From \\ Corporations to Social \\ Entrepreneurs: \\ Exploring the Different \\ Faces of Social Innovation \\ (April 17th - 18th, 2020, \\ Dubrovnik, Croatia, \\ Governance Research and \\ Development Centre \\ CIRU), Zagreb, pp. 35-46
}

\section{INTRODUCTION}

Corporate governance is defined in the international literature (OECD, 2015) as the set of relationships between a company's management and its stakeholders. The first definition of the concept dates back to 1992 and presents corporate governance as the set of rules by which companies are directed and controlled (Cadbury Report, 1992), trying to provide an answer to the question how shareholders are getting a return on their investment (La Porta et al., 2000).

The Organisation for Economic Cooperation and Development (OECD) is one of the organisations that have been particularly involved in the implementation of certain provisions, structures and mechanisms of corporate governance, the developed principles being guidelines, rules 
of good practice for the organisation of companies and their way of reporting relationships with third parties (O. Jula, 2017). An essential feature of the Corporate Governance Codes is that they are implemented on the basis of the "Comply or Explain" principle which discloses to the market clear, accurate and up-to-date information regarding the compliance of the listed companies with the corporate governance rules, avoiding the "one size fits all" framework (Seidl et al., 2013).

In other words, a good corporate governance can be translated through efficient rules, policies and procedures of business management, administration and control. It is essential for companies that want to reduce operational and financial risks, increase performance, open towards new markets and add more value to the relationship with their current and potential investors (Fulop. M, et al.2015).

In Romania, the concept of corporate governance appeared at the beginning of the $2000 \mathrm{~s}$, being initially governed by the Code of Management and Administration of the Bucharest Stock Exchange. (Apostol C.,2015).

According to BSE (2015), the purpose of the Corporate Governance Code is to create in Romania an internationally attractive capital market, based on best practices, transparency and trust. To achieve these goals, listed entities must comply to a great extent with the principles and provisions elaborated by the Bucharest Stock Exchange.

Researchers such as Vintilă G. and Moscu R. (2014) studied the level of compliance for 55 entities listed on the BSE in 2013 and found that the degree of compliance with the Code of Corporate Governance of BSE is achieved at a rate of $70.6 \%$, the lowest score is based on a result of $21.1 \%$ and the highest is $92.3 \%$. Rose C. (2016) investigates the degree of Danish firm adherence to the Danish Code of Corporate Governance and analyzes whether a higher degree of comply or explain disclosure is related to firm performance. His analysis shows that there is a positive link between Return on Equity / Return on Assets and Danish firm total corporate governance comply or explain disclosure scores. In their study Madanoglua $\mathrm{M}$ et al. (2018) defends the view that the adoption of corporate governance provisions should not be seen as a detriment to firms' financial performance. Using a settheoretic method, such as the Qualitative Comparative Analysis (QCA), his findings revealed that there are three configurations of governance provisions that lead to superior financial performance.

The purpose of this study is to present the results of an analysis carried out on the companies listed on the main market of the Bucharest Stock Exchange in order to measure their degree of compliance with the principles and provisions of the Corporate Governance Code developed by the BSE in relation to the aspects regarding the responsibilities of the Board of Directors in the case of the individually managed companies or of the Supervisory Board / Directorate in the dualistic system, the risk management system and the internal control, the fair reward and motivation of the members of these boards and the value added through the relationship with the current and potential investors.

\section{MATERIALS AND METHODS}

PAGE 56| Journal of Corporate Governance, Insurance, and Risk Management | 2020, VOL. 7, Series. 2 
In this paper we aim to measure the degree to which the companies listed on the Bucharest Stock Exchange (BSE) comply with the provisions and principles of the Corporate Governance Code developed by the BSE with regard to the responsibilities of the management, the risk management system and the internal control, the fair reward and motivation of the members of the Board of Directors or the Supervisory Board and the added value created through the relationship with the current and potential investors.

By means of the corporate governance statement, included in the Annual Report in a separate section, the listed companies perform a self-assessment of how "the provisions to be observed" are met and outline the measures taken to comply with the aspects that are not fully met. The research methodology used, the observation, was based mainly on the analysis of the Annual Reports and of the Comply or Explain Statement published by the entities analysed in 2018. Out of the 87 companies included in the Monthly Bulletin drawn up by the BSE in December 2018, a document presenting the main stock market indicators of the listed companies, we excluded from our analysis the companies that incurred losses in 2018 and those that did not draw up the Comply or explain statement (the main source of our data), thus keeping a number of 61 companies.

According to the Corporate Governance Code (BSE, 2015), the provisions and principles to be observed by the listed companies are structured in four sections, as follows:

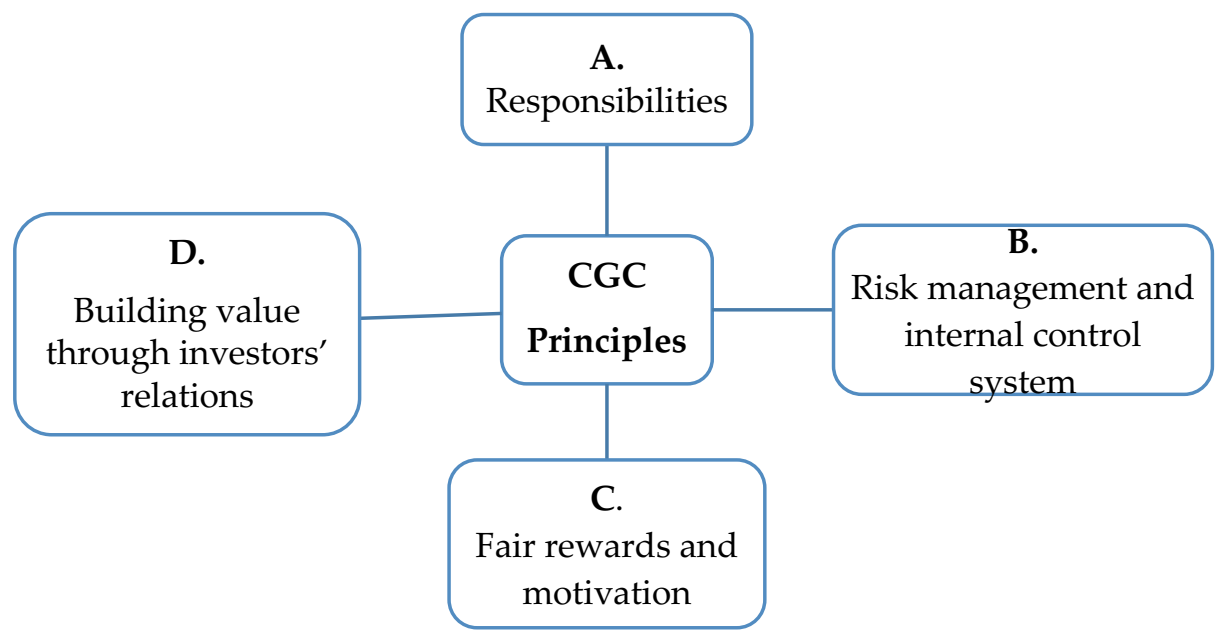

Figure 1. Sections of Corporate Governance Code

Source: own projection after BSE

Table 1. Corporate Governance principles and provisions

Section A-Responsibilities

A.1. All companies should have internal regulation of the Board which includes terms of reference/responsibilities for Board and key management functions of the company, applying,

PAGE 57| Journal of Corporate Governance, Insurance, and Risk Management | 2020, VOL. 7, Series. 2 
among others, the General Principles of Section A.

A.2. Provisions for the management of conflict of interest should be included in Board regulation.

A.3. The Board of Directors or the Supervisory Board should have at least five members.

A.4. The majority of the members of the Board of Directors should be non-executive. At least one member of the Board of Directors or Supervisory Board should be independent, in the case of Standard Tier companies. Not less than two non-executive members of the Board of Directors or Supervisory Board should be independent, in the case of Premium Tier Companies.

A.5. A Board member's other relatively permanent professional commitments and engagements, including executive and non-executive Board positions in companies and not-forprofit institutions, should be disclosed to shareholders and to potential investors before appointment and during his/her mandate.

A.6. Any member of the Board should submit to the Board, information on any relationship with a shareholder who holds directly or indirectly, shares representing more than $5 \%$ of all voting rights. This obligation concerns any kind of relationship which may affect the position of the member on issues decided by the Board.

A.7. The company should appoint a Board secretary responsible for supporting the work of the Board.

A.8. The corporate governance statement should inform on whether an evaluation of the Board has taken place under the leadership of the chairman or the nomination committee and, if it has, summarize key action points and changes resulting from it. The company should have a policy/guidance regarding the evaluation of the Board containing the purpose, criteria and frequency of the evaluation process.

A.9. The corporate governance statement should contain information on the number of meetings of the Board and the committees during the past year, attendance by directors (in person and in absentia) and a report of the Board and committees on their activities.

A.10. The corporate governance statement should contain information on the precise number of the independent members of the Board of Directors or of the Supervisory Board.

Section B - Risk management and internal control system

B.1. The Board should set up an audit committee, and at least one member should be an independent non-executive. The majority of members, including the chairman, should have proven an adequate qualification relevant to the functions and responsibilities of the committee. At least one member of the audit committee should have proven and adequate auditing or accounting experience. In the case of Premium Tier companies, the audit committee should be composed of at least three members and the majority of the audit committee should be independent. 


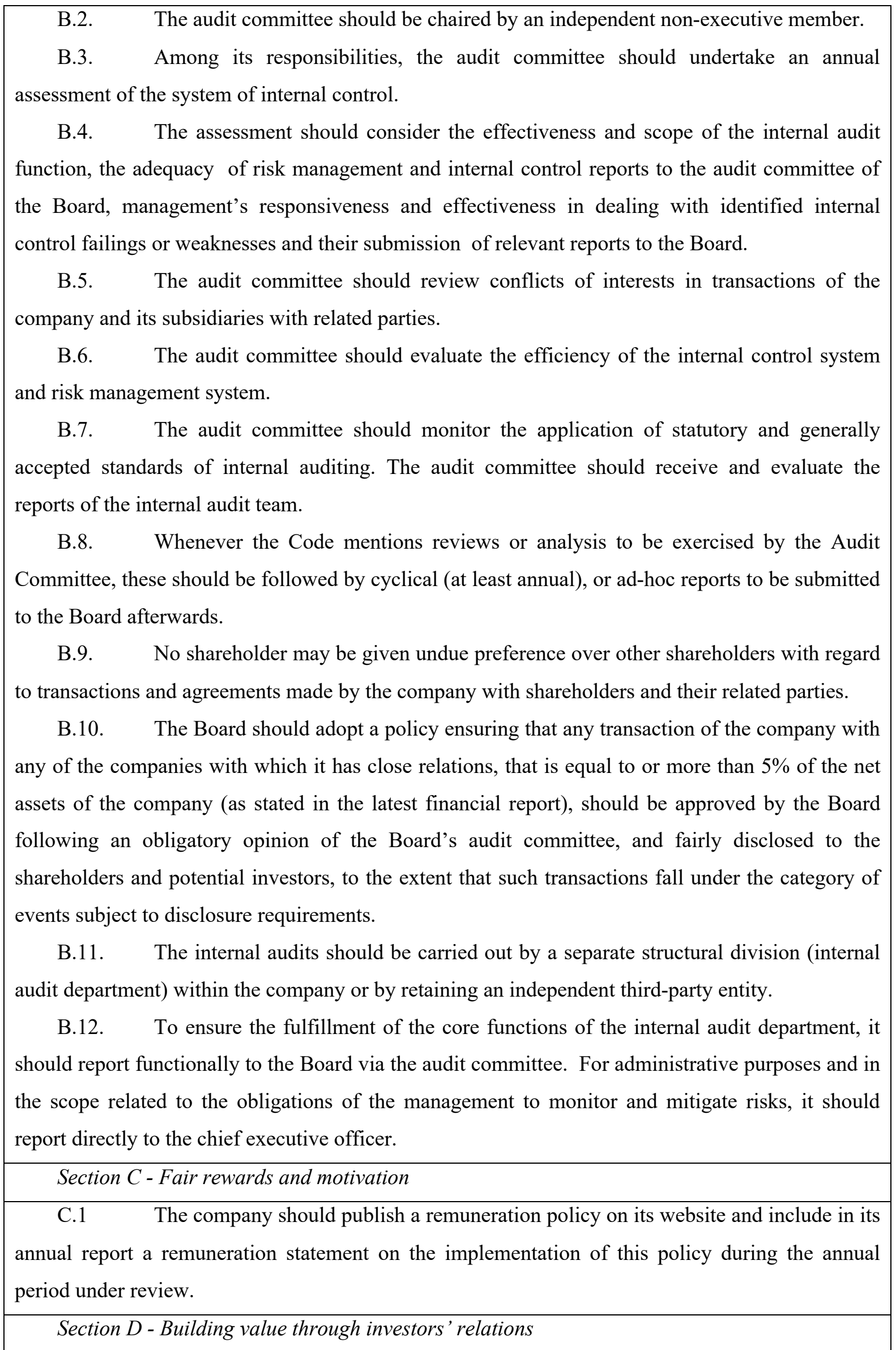


D.1. The company should have an Investor Relations function - indicated, by person (s) responsible or an organizational unit, to the general public. In addition to information required by legal provisions, the company should include on its corporate website a dedicated Investor Relations section, both in Romanian and English, with all relevant information of interest for investors

D.2. A company should have an annual cash distribution or dividend policy, proposed by the CEO or the Management Board and adopted by the Board, as a set of directions the company intends to follow regarding the distribution of net profit. The annual cash distribution or dividend policy principles should be published on the corporate website.

D.3. A company should have adopted a policy with respect to forecasts, whether they are distributed or not. Forecasts means the quantified conclusions of studies aimed at determining the total impact of a list of factors related to a future period (so called assumptions): by nature such a task is based upon a high level of uncertainty, with results sometimes significantly differing from forecasts initially presented. The policy should provide for the frequency, period envisaged, and content of forecasts. Forecasts, if published, may only be part of annual, semi-annual or quarterly reports. The forecast policy should be published on the corporate website

D.4. The rules of general meetings of shareholders should not restrict the participation of shareholders in general meetings and the exercising of their rights. Amendments of the rules should take effect, at the earliest, as of the next general meeting of shareholders.

D.5. The external auditors should attend the shareholders' meetings when their reports are presented there.

D.6. The Board should present to the annual general meeting of shareholders a brief assessment of the internal controls and significant risk management system, as well as opinions on issues subject to resolution at the general meeting.

D.7. Any professional, consultant, expert or financial analyst may participate in the shareholders' meeting upon prior invitation from the Chairman of the Board. Accredited journalists may also participate in the general meeting of shareholders, unless the Chairman of the Board decides otherwise

D.8. The quarterly and semi-annual financial reports should include information in both Romanian and English regarding the key drivers influencing the change in sales, operating profit, net profit and other relevant financial indicators, both on quarter-on-quarter and year-on-year terms.

D.9. A company should organize at least two meetings/conference calls with analysts and investors each year. The information presented on these occasions should be published in the IR section of the company website at the time of the meetings/ conference calls.

D.10. If a company supports various forms of artistic and cultural expression, sport activities, educational or scientific activities, and considers the resulting impact on the innovativeness and 
competitiveness of the company part of its business mission and development strategy, it should publish the policy guiding its activity in this area.

Source: BSE Corporate Governance Code

For the entities included in our study we used a scoring system that reflects the extent to which they comply with the provisions and principles presented above, thus transforming the enunciative data into numerical, quantitative data, in order to measure the companies' ability in implementing "good" corporate governance practices (Udo Braendle, 2019). Taking into account the fact that in the Comply or explain statement the companies have three options through a self-assessment that reflects the full compliance, partial compliance or non-compliance, the following table reflects the scoring system used according to the response published by the studied companies:

\section{Table 2. Conformity marks}

\begin{tabular}{cl}
\hline Conformity mark & \multicolumn{1}{c}{ Significance } \\
\hline $\mathbf{3}$ & Full compliance with the principles and provisions \\
$\mathbf{1}$ & Partial compliance \\
$\mathbf{0}$ & Non-compliance \\
& Source: author's own projection
\end{tabular}

Considering the 4 sections of the Code and the proposed scoring system, for section A a company can obtain a maximum of 30 points, for section $B$ a maximum of 36 points, for section $C, 3$ points and for section D a maximum of 30 points. In total, a company can sum up 99 points, which reflects total compliance in all sections of the Corporate Governance Code. For the studied companies, the maximum score that can be reached is 6,039 points.

\section{RESULTS AND DISCUSSIONS}

The analysis of the Comply or explain statement made for each of the 61 entities studied in accordance with the scoring system, highlights the following level of conformity with the Code's provisions and principles:

\begin{tabular}{lccc}
\hline \multicolumn{4}{c}{ Tabel 3. Level of conformity with the Code s provisions } \\
\hline Category & $\begin{array}{c}\text { Maxim } \\
\text { um score }\end{array}$ & $\begin{array}{c}\text { Obtain } \\
\text { results }\end{array}$ & $\begin{array}{c}\text { Comply assessment } \\
(\% * \text { maximum score })\end{array}$ \\
\hline Total CGC score & 6.039 & 4.706 & $78 \%$ \\
\hline Section A score & 1.830 & 1.487 & $81 \%$ \\
Section B score & 2.196 & 1.690 & $77 \%$
\end{tabular}

PAGE 61| Journal of Corporate Governance, Insurance, and Risk Management | 2020, VOL. 7, Series. 2 


$\begin{array}{lccc}\text { Section C score } & 183 & 100 & 55 \% \\ \text { Section D score } & 1.830 & 1.429 & 78 \%\end{array}$

Source: author's own projection

From the analysis carried out we can see that the studied entities comply to a great extent with the provisions of the Corporate Governance Code. The lowest result was obtained in section $\mathrm{C}$, which refers to the remuneration policy which must be based on the fair reward and motivation for the members of the Council and for the CEO or the members of the Directorate. $45 \%$ of the studied entities do not publish the remuneration policy on the companies website and do not include information on its implementation in the Annual report.

The section analysis of the level of compliance with the provisions and principles of the Code reflects the following:

Table 4. Descriptive statistics for section

A

\begin{tabular}{lr}
\hline \multicolumn{2}{c}{ Section A-conformity score } \\
\hline Mean & 24.3770 \\
Standard Error & 0.8772 \\
Median & 27 \\
Mode & 30 \\
Standard Deviation & 6.8511 \\
Sample Variance & 46.9387 \\
Kurtosis & 1.2300 \\
Skewness & -1.4614 \\
Range & 27 \\
Minimum & 3 \\
Maximum & 30 \\
Sum & 1487 \\
Count & 61
\end{tabular}

Source: own projection

The mean of the scores obtained in section A is 24.38 , with the median 27 and the mode 30 . The lowest score obtained is 3 , which reveals that out of the 61 companies under study some do not comply with the provisions of the Governance Code in terms of the existence of an internal operating regulation for the specialised committees or the composition, the independence and the quality of nonexecutive members of the Board of Directors is not compliant with the requirements of the Code, there being no clear distinction between executive and non-executive members of the Board of Directors. The highest score and the maximum of the section, the value 30 , is obtained by companies that fully 
comply with the provisions of the code in terms of the responsibilities of the Board. Within this section, the model's amplitude is 27 and it reflects the difference between the maximum and the minimum score obtained by the companies under study.

Graphically, the results obtained by the studied entities regarding the level of compliance with the provisions of section A are reflected as follows:

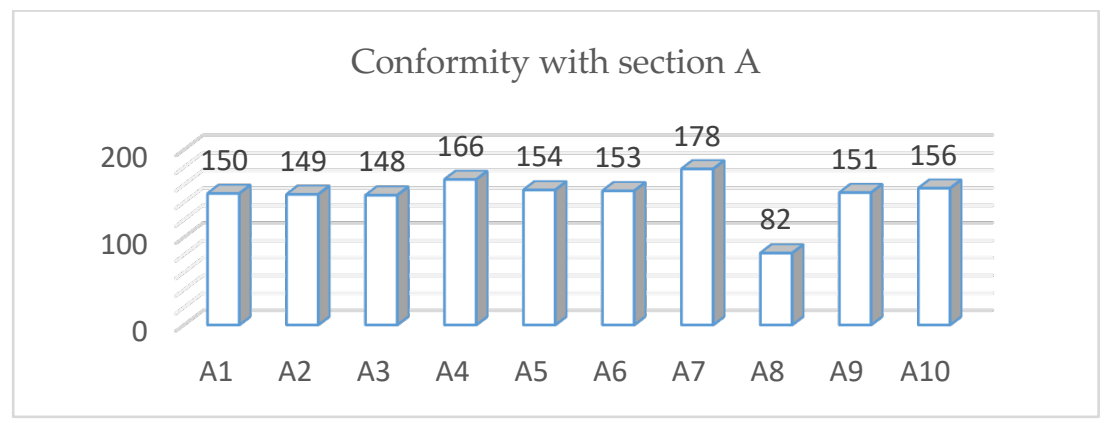

Figure 2. Conformity with section A

Source: own projection

From the previous figure we can see that out of the total of 183 points per section (full compliance of all the entities/section), the studied companies are approaching to this value, which means a satisfactory level of compliance with the provisions of the code. In a single section, A8, the results are below average, because most of the companies do not have a policy to evaluate the Council that reflects the purpose, the criteria and the frequency of the evaluation process.

Table 5. Descriptive statistics for section

B

\begin{tabular}{lr}
\hline \multicolumn{2}{c}{ Section B-conformity score } \\
\hline Mean & 27.7049 \\
Standard Error & 1.4597 \\
Median & 33 \\
Mode & 36 \\
Standard Deviation & 11.4007 \\
Sample Variance & 129.9781 \\
Kurtosis & -0.0523 \\
Skewness & -1.2091 \\
Range & 36 \\
Minimum & 0 \\
Maximum & 36 \\
Sum & 1690 \\
Count & 61
\end{tabular}

PAGE 63| Journal of Corporate Governance, Insurance, and Risk Management | 2020, VOL. 7, Series. 2 
The mean of the scores obtained in section B is 27.70 , with the median 33 and the mode 36 . The lowest score obtained is 0 which reveals that out of the 61 companies under study some do not comply with the provisions of the Governance Code in terms of establishing the Audit Committee to periodically examine the efficiency of the financial reporting, of the internal control and of the risk management system. Moreover, the companies neither comply with the principles of governance in terms of the independence and the non-executive independent member status for at least one person within the structure. The highest score and the maximum of the section, the value 36 , is obtained by companies that fully comply with the provisions of the code. Within this section, the model's amplitude is 36 and it reflects the difference between the maximum and the minimum score obtained by the companies under study.

Graphically, the results obtained by the studied entities regarding the level of compliance with the provisions of section B are reflected as follows:

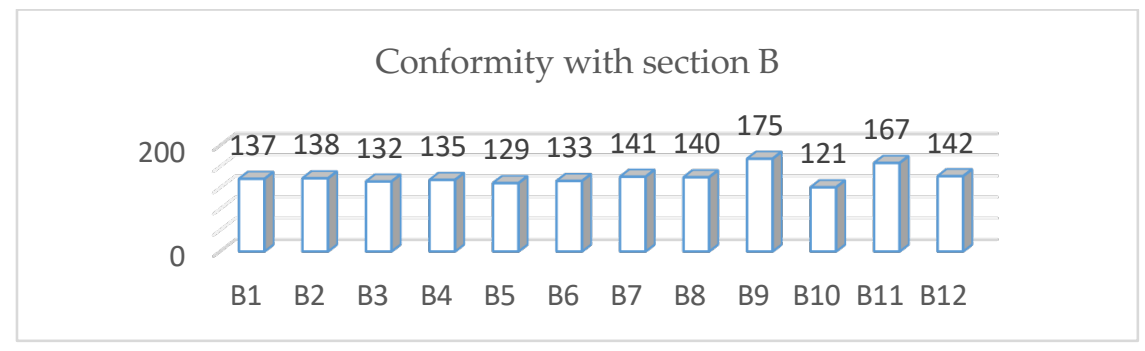

Figure 3. Conformity with section B

Source: own projection

From the previous figure we can see that out of the total of 183 points per section (full compliance of all the entities/section), most entities obtain a score above average, which means a satisfactory level of compliance with the provisions of the code.

Table 6. Descriptive statistics for

section C

\begin{tabular}{lr}
\hline \multicolumn{2}{c}{ Section C-conformity score } \\
\hline Mean & 1.6393 \\
Standard Error & 0.1734 \\
Median & 1 \\
Mode & 3 \\
Standard Deviation & 1.3544 \\
Sample Variance & 1.8344 \\
Kurtosis & -1.8489
\end{tabular}

PAGE 64| Journal of Corporate Governance, Insurance, and Risk Management | 2020, VOL. 7, Series. 2 
Skewness

Range

Minimum

Maximum

Sum

Count
$-0.0974$

Source: own projection

The mean of the scores obtained in section $\mathrm{C}$ is 1.63 , with the median 1 and the mode 3 . The lowest score obtained is 0 which reveals that out of the 61 companies under study some do not comply with the provisions of the Governance Code regarding the publication of the principles and arguments underlying the remuneration policy of the members of the Board of Directors or of the members of the Directorate. The highest score and the maximum of the section, the value 3 , is obtained by companies that fully comply with the provisions of the code. Within this section, the model's amplitude is 3 and it reflects the difference between the maximum and the minimum score obtained by the companies under study.

Graphically, the results obtained by the studied entities regarding the level of compliance with the provisions of section $\mathrm{C}$ are reflected as follows:

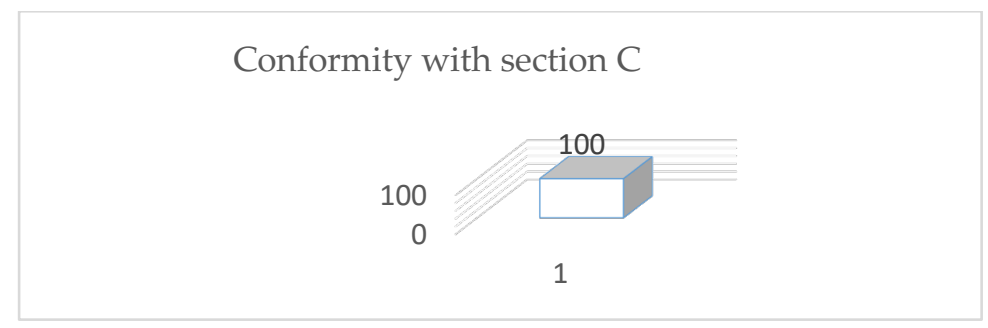

Figure 4. Conformity with section C

Source: own projection

In section $\mathrm{C}$ there is only one provision that must be respected by the listed entities which refers to the fair reward and motivation regarding the remuneration policy of the members of the Council and of the CEO, as well as of the members of the Directorate in the dualistic system. The results obtained reflect the above average compliance of the entities with the provisions of the code.

\begin{tabular}{lr}
\hline \multicolumn{2}{c}{ Table 7. Descriptive statistics for section D } \\
\hline \multicolumn{2}{c}{ Section D-conformity score } \\
\hline Mean & 23.4262 \\
Standard Error & 0.7601
\end{tabular}


Median

Mode

Standard Deviation

Sample Variance

Kurtosis

Skewness

Range

Minimum

Maximum

Sum

Count

Source: own projection

The mean of the scores obtained in section D is 23.43 , with the median 24 and the mode 30 . The lowest score obtained is 5 which reveals that out of the 61 companies under study some do not comply with the provisions of the Governance Code regarding the organization of the investor relations service, the annual dividend distribution policy, forecasts, the participation of external auditors at the General Shareholders' Meetings when their reports appear on the agenda of the meetings, key factors influencing the development as well as publishing on the company's website the information presented during the annual meetings with analysts and investors. The highest score and the maximum of the section, the value 30 , is obtained by companies that fully comply with the provisions of the code. Within this section, the model's amplitude is 25 and it reflects the difference between the maximum and the minimum score obtained by the companies under study.

Graphically, the results obtained by the studied entities regarding the level of compliance with the provisions of section $\mathrm{D}$ are reflected as follows:

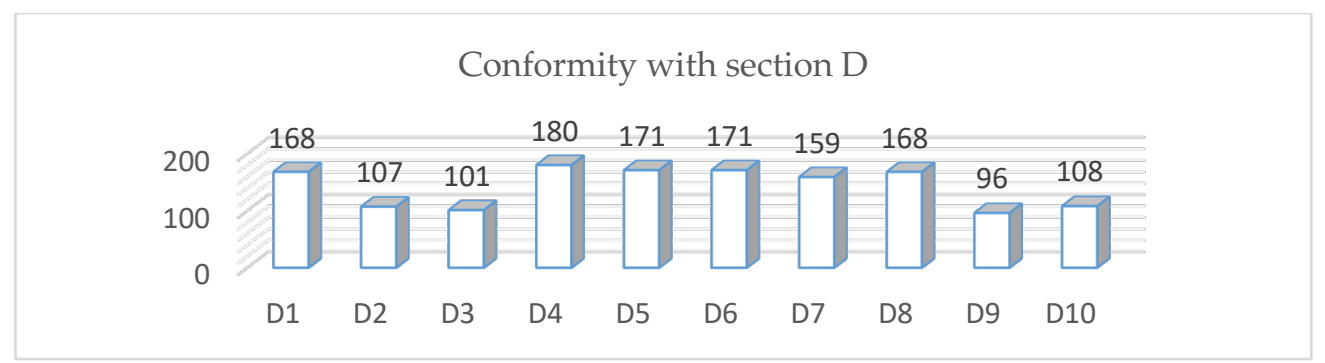

Figure 5. Conformity with section D

Source: own projection

From the previous figure we can see that out of the total of 183 points per section (full compliance of all the entities/section), most entities score above average, which means a satisfactory PAGE 66| Journal of Corporate Governance, Insurance, and Risk Management | 2020, VOL. 7, Series. 2 
level of compliance with the provisions of the code. Only one provision, D9, records a lower score, respectively the one that states that a company should organize at least two meetings/conference calls with analysts and investors each year and the information presented on these occasions should be published in the IR section of the company website.

From a global perspective, the level of compliance with the provisions and principles of the code of the 61 studied entities is presented as follows:

\begin{tabular}{lr}
\hline \multicolumn{2}{c}{$\begin{array}{c}\text { Table 8. Descriptive statistics for total } \\
\text { Corporate Governance score }\end{array}$} \\
\hline \multicolumn{2}{c}{ Total CGC score } \\
\hline Mean & 77.1475 \\
Standard Error & 2.9027 \\
Median & 86 \\
Mode & 93 \\
Standard Deviation & 22.6714 \\
Sample Variance & 513.9945 \\
Kurtosis & 0.5692 \\
Skewness & -1.2484 \\
Range & 87 \\
Minimum & 12 \\
Maximum & 99 \\
Sum & 4706 \\
Count & 61
\end{tabular}

Source: own projection

The total mean of the scores obtained is 77.14 points out of a total of 99 points / entity with the median 86 and the mode 93. The lowest score obtained is 12 which reveals that out of the 61 companies under study there are entities that comply to a very low extent with the provisions of the Governance Code on the 4 sections, respectively regarding the responsibilities of the management, the risk management system and the internal control, the just reward and motivation of the members of the Board of Directors or Supervision and the added value created through the relationship with current and potential investors. The highest score, the maximum, the value 99 , is obtained by companies that fully comply with the provisions of the code. Within this section, the model's amplitude is 87 and it reflects the difference between the maximum and the minimum score obtained by the companies under study. 
In a general approach, we can state that the scores obtained by the companies included in the research reflect a high degree of compliance with the principles of corporate governance.

\section{CONCLUSIONS}

This study has focused on the compliance of the listed entities on Main Market of the Bucharest Stock Exchange with the Corporate Governance Code principles and provisions.

After processing and analysing the data collected from the Comply or Explain Statement published by the listed entities included in the study, we can outline the following aspects regarding the degree of compliance with the principles of corporate governance:

- the Comply or Explain statement reflects the extent to which the corporate governance rules are observed by the listed entities through a self-assessment that reflects the full compliance, partial compliance or non-compliance with the provisions of the Code. The statement can be included in the Annual Report or can be presented separately;

- the implementation of the provisions and principles of the governance code ensures transparency, trust for both current and potential investors, as well as the fair treatment of shareholders in relation to the access to information because the statement describes the aspects regarding the administration and the control of the company;

- we may notice the companies' favourable perception on the need to adopt the principles of corporate governance;

- as a consequence, we consider that the companies under study show a high degree of compliance with the principles of corporate governance developed by the BSE, thus understanding that good corporate governance can ensure the sustainable development of the company.

The contribution of the current study is to provide information regarding Corporate governance in Romania and the degree of compliance with the principles and provisions of the listed entities. Our main research tool, the corporate governance index, calculated after a framework proposed by the authors for 61 listed entities in Romania reflects a high degree of compliance. We believe that the ease of access to additional funds, the increase of transparency in reporting, the sustainable development in the context of globalisation and the increase of the market value of the company are the benefits of an efficient corporate governance system that can represent a competitive advantage to any economic entity.

Author Contributions: Conceptualization, O.B. and A.D.; methodology, O.A and A.D.; software, O.B.; validation, O.B; formal analysis, O.B. and A.D.; investigation, O.B.; resources, O.B.; data curation, O.B. and A.D.; writing-original draft preparation, O.B. and A.D.; writing-review and editing, O.B.; visualization, A.D.; supervision, A.D.; project administration, O.B. and A.D.; All authors have read and agreed to the published version of the manuscript.

Funding: This research received no external funding 
Conflicts of Interest: The authors declare no conflict of interest.

\section{REFERENCES}

Apostol C. 2015. Adoptarea bunelor practici de guvernanță corporativă de către companiile din România, Colecţia Cercetare avansată postdoctorală în ştiinţe economice, ISBN 978-606-505-959-7, Editura ASE, București.

Braendle, U. 2019. Corporate governance code compliance and financial performance: the case of Austrian Stock lised companies, Investment Management and Financial Innovation, Volume 16, Isssue 3, 131-141.

Bucharest Stock Exchange - Corpoarte Governance Code. 2015. Available on-line: www.bvb. Cadbury, A. 1992. The Financial Aspects of Corporate Governance, Gee and Co. Ltd., London, UK. Fulop, M., Pintea, M.2015. The link between corporate governance and performance-evidence from Romania, Management intercultural, Volumul XVII, Nr.1 (33). Statements of Conformity " Comply or Explain" of the companies listed on the Bucharest Stock Exchange taken from Annual reports . Retrived from: www. bvb.ro

Jula, O. 2017. Guvernanța corporativă - necesitate sau și inovație? Expertiza şi auditul afacerilor, No.30-31.

La Porta, R., Lopez de Silanes, F., Schleifer, A., Vishny, R.W. 2000. Investor protection and corporate governance. Journal of Finance Economics, 58 (1-2), 3-27.

Madanoglua, M., Kizildagb, M., Ozdemirc, O. 2018. Which bundles of corporate governance provisions lead to high firm performance among restaurant firms? International Journal of Hospitality Management, no. 72, 98-108.

OECD 2015. Principles of Corporate Governance https://www.oecd.org/corporate/principlescorporate-governance.htm

Rose, C. 2016. Firm performance and comply or explain disclosure in corporate governance, European Management Journal, no. 34, 202-222.

Vintilă, G., Moscu, R. 2014. Compliance with the romanian corporate governance code. Evidences from the companies listed on Bucharest Stock Exchange, Journal of Public Administration, Finance and Law, Issue 6/2014.

Seidl, D., Sanderson, P., Roberts, J. 2013. Applying the „comply or explain” principle: discursive legitimacy tactics with regard to codes of corporate governance, Journal of Management and governance, 17, 791-826 